\title{
Molecular Cloning and Chartacterization DNA Polymerase I from thermophilic Geobacillus SBS 4S strain
}

farheen aslam ( $\square$ farheenpu@gmail.com )

Lahore college for women university

Saima Iftikhar Bajwa

University of the Punjab

Research article

Keywords: DNA Polymerase I, hyperthermophile, Geobacillus, Isopropyl $\beta$-d-1-thiogalactopyranoside (IPTG)

Posted Date: November 11th, 2019

DOI: https://doi.org/10.21203/rs.2.16972/v1

License: (c) (i) This work is licensed under a Creative Commons Attribution 4.0 International License.

Read Full License 


\section{Abstract}

Thermostable DNA polymerases are extensively used in biotechnology and life science applications. DNA Polymerase I was isolated from a hyperthermophile bacteria Geobacillus SBS 4S. Primers were designed using the template sequence of DNA Polymerase I gene of Geobacillus kaustophilus HTA26 strain. Nco 1 and Hind III sites were introduced on the forward and reverse primers respectively. Polymerase I gene of $2.6 \mathrm{~Kb}$ was cloned in pTZ57/ RT vector. Cloned gene of Polymerase I was restricted with Nco 1 and Bam $\mathrm{H} 1$, and ligated to $\mathrm{pET} 22 \mathrm{~b}$ vector. Nco 1 site was used to insert twenty two N-terminal aminoacids (pelB) leader sequence at the start of the gene, which lead the recombinant protein in the periplasmic space, which increases the half life of recombinant protein. pelB fused with DNA Polymerase I produces soluble protein, which was detected after sonication. Sequencing shows that DNA polymerase I consists of 2499 bp with encodes for 832 amino acids, showed $99 \%$ similarity with Geobacillus Kaustophillus . The expression of pelB fused DNA Polymerase I was optimized at different concentrations of IPTG and lactose. Highest expression was observed with $0.5 \mathrm{mM}$ IPTG and $20 \mathrm{mM}$ lactose. After Harvesting and sonication of BL21 codon plus cells, Polymerase I was produced in the soluble fraction. The supernatant containing the protein of interest, was separated after centrifugation at 10,000 rpm for $20 \mathrm{~min}$. The protein was purified by ammonium sulphate precipitation and cation exchange column. The activity of purified DNA Polymerase I was checked by PCR reaction.

\section{Background}

DNA polymerases are key enzymes that are involved into DNA replication and repair processes that occur in all living organisms (1). Thermostable DNA polymerases are produced by thermophilic bacteria are valuable source of DNA polymerases. Thermophilic and hyperthermophilic enzymes have more importance over mesophilic enzymes, the most important application of thermostable enzyme is DNA polymerase.The most important application of DNA polymerase is in PCR. In prokaryotes there are three main types of DNA polymeases, Polymerase I, II and III. DNA polymerase III is the enzyme involved in DNA synthesis, whereas $P o l I$, and II has polymerase as well as exonuclease activity.

Synthesis of DNA by DNA polymerase occur in four steps. In the first step polymerase enzyme binds to the template primer dimer. In the second step dNTPS binds to enzyme template primer complex, in the third step phosphodiester bond is formed as a result of nucleophilic attack, In the final step a conformational change cause elimination of pyrophosphate moiety (2).

The first DNA polymerase was isolated by Kornberg and colleagues from E.coli in 1950s. This polymerase contains all three basic activities, $3^{\prime}-5^{\prime}$ exonuclease, $5^{\prime}-3^{\prime}$ exonuclease and polymerase activities. Up to today more than 100 DNA polymerases have been cloned and sequenced from many organisms including thermophile and archea. Most of the thermostable DNA polymerases have been isolated from Thermus genus especially from Thermus aquaticus. Taq polymerase is the first thermostable enzyme that has been characterized. DNA polymerases from thermophiles lack $3^{\prime}-5^{\prime}$ exonuclease activity while others from hyperthermophiles retain all the three basic activities of E.coli 
polymerases(3). A few of thermostable DNA polymerases have also been characterized and purified from the thermophilic members of family Bacillacaece especially from genus Bacillus and new genus Geobacillus: B. stearothermophilus, B. caldoxylolyticus, B. caldotenax etc. DNA polymerase from Bacillus stearothermophilus is used in sequencing reactions (4).

Genus Geobacillus was proposed by Nazina et al Geobacillus showed strong similarity to B. kaustophilus, $B$. stearothermophilus, $B$. thermocatenulatus, $B$. thermodenitrificans, $B$. thermoglucosidasius, and B.thermoleovorans. species belonging to this genus have unique properties like rod shaped cells, aerobic or facultative aerobic cylindrical endospore formers, with optimum growth temperature at $37-75^{\circ} \mathrm{C}$. Bacteria belonging to genus Geobacillus shows optimum growth at $65^{\circ} \mathrm{C}$ and $\mathrm{pH}, 6.05-8.0$ (5).

\section{Methods}

Samples of Geobacillus SBS 4S was taken from Prof. Dr. Naeem Rashid (School of Bioloical Sciences). Total DNA was isolated from bacterial cell, using classical method of Sambrook and Russels.(6) All the chemicals and kits. PCR ampilifaction kit was from Thermofisher Scientific. For plasmid DNA extraction "Vivantis Nucleic Acid Extraction" kit was used. InsTAclone ${ }^{T M}$ PCR cloning kit was of vivantis. EcoRI, HindIII and BamH1was from Thermofisher Scientific. Thermo Scientific GeneJet ${ }^{\mathrm{TM}}$ MiniprepKit.

\section{PCR amplification and primer designing}

The sequence of DNA Polymerase I of Geobacillus kaustophilus was retrieved from NCBI database (GenBank: JYBP01000003.1). Primers were designed manually and checked on oligo nucleotide property calculator. Restriction sites were introduced at the start and end of the gene. One forward (Pol-F), one reverse primer (Pol-R) and one internal primer (Pol-I) were designed (Table 1).

PCR optimized with $0.15 \mathrm{mM} \mathrm{MgCl}_{2}, 0.25 \mathrm{mM}$ DNTPS, 100 pmoles of forward (Pol-F) and reverse primer (Pol-R) and $5 \mathrm{U}$ of Taq DNA polymerase (Fermentas). PCR was performed with initial denaturation at $94^{\circ} \mathrm{C}$ for $3 \mathrm{~min}$, denaturation at $94^{\circ} \mathrm{C}$ for $30 \mathrm{sec}$, annealing at $55^{\circ} \mathrm{C}$ for $90 \mathrm{sec}$, extension at $72^{\circ} \mathrm{C}$ for $1 \mathrm{~min}$ and final extension at $72{ }^{\circ} \mathrm{C}$ for $10 \mathrm{~min}$. The PCR product was extracted by Vivantis Quick Gel Extraction kit. The PCR samples was visualized on agarose gel and "Vivantis Nucleic Acid Extraction" kit was used to extract PCR product from agarose gel.

\section{Cloning and Transformation of DNA polymerase I in pTZ57R/T vector}

After Gene clean purified gene (2.6 kB) sample was cloned into cloning vector using ligation kit (InsTAclone ${ }^{T M}$ PCR cloning kit). PCR product (2.6kB) Vector pTZ57R/T were mixed with $10 \mathrm{X}$ ligation buffer (3ul) and incubated at $22^{\circ} \mathrm{C}$ for overnight in water bath. $\mathrm{DH}_{5} \mathrm{a}$ competent cells were transformed with ligated plasmids (Pol-pTZ57R/T5.4). $200 \mathrm{ul}$ of competent cells and $15 \mathrm{ul}$ of ligation mixture was incubated on ice for $40 \mathrm{~min}$. then $90 \mathrm{sec}$ heat shock was given to the sample and immediately placed sample on ice for $5-10 \mathrm{~min}$. After adding $800 \mathrm{ul}$ of LB media into eppendorf sample mixture was placed 
in shaker for $2 \mathrm{hr}$ incubation. $200 \mathrm{ul}$ of sample was taken and spread on 2 agar plates $(1.5 \%$ agar, 100 $\mu \mathrm{g} / \mathrm{ml}$ of ampicillin, $1.33 \mu \mathrm{g} / \mathrm{ml}$ 5-bromo-4-chloro-3-indolyl- $\beta$-D-galactoside (X-gal) and $35 \mu \mathrm{g} / \mathrm{ml}$ of 0.4 $M$ isopropylthio- $\beta$-D-galactoside (IPTG). Plates were placed in oven at $37^{\circ} \mathrm{C}$ overnight. Pol-pTZ57R/T5.4 was isolated with Thermo Scientific GeneJet ${ }^{\mathrm{TM}}$ MiniprepKit.

The sequencing of Polymerase I gene was done with forward and reverse primers of M13 and internal primer (Pol-1) on Beckman Coulter (CEQTM 8000 DNA sequencer). Sequence was aligned with Clustal W and DDBJ (DNA Data bank Japan).

Cloning and Transformation of DNA polymerase I in $p E T 22 b$ vector

Pol-pTZ57R/T vector was restricted with $\mathrm{Ncol}$ first, in $50 \mathrm{ul}$ reaction mixture, with $25 \mathrm{U}$ of $\mathrm{Nco} 1$ and $1 \mu \mathrm{g}$ of Pol-pTZ57R/T vector and incubated at $37^{\circ} \mathrm{C}$ for $3 \mathrm{hrs}$. The reaction mixture was kept at $-20^{\circ} \mathrm{C}$ overnight. Next day $25 \mathrm{U}$ of $\mathrm{BamH} 1$ was added and incubated at $37^{\circ} \mathrm{C}$ for $3 \mathrm{hr}$. Sample was visualized on the agarose gel. Polymerase I gene insert $(2.6 \mathrm{~kb})$ was ligated to pET22b vector in a $30 \mu \mathrm{l}$ reaction with gene to vector ratio of $3: 1$ and $100 \mathrm{U}$ of T4 DNA ligase and incubated at $22{ }^{\circ} \mathrm{C}$ overnight. Presence of insert (pol) into pET 22b vector was confirmed with double digestion with $\mathrm{Ncol}$ and $\mathrm{BamHI}$.

\section{Expression of Polymerase I in codon plus BL-21 cells}

Pol-pET22b8.0 was transformed to BL-21 codon plus cells. Single transformed colony was inoculated in $10 \mathrm{ml} \mathrm{LB}$ ampicilin flask and incubated at $37^{\circ} \mathrm{C}$ in shaker overnight. $1 \mathrm{ml}$ culture was taken from inoculum and inoculated in $50 \mathrm{ml}$ LB fresh media flask and incubated at $37^{\circ} \mathrm{C}$ in shaker until optical density (OD) 600 reached to 0.4-0.6. At this stage 0.05, 0.1, 0.2, 0.5 mM IPTG and 2, 5, 1015 and $20 \mathrm{mM}$ lactose was added to the culture and incubated for 5-6 hours. From this induced culture pellet was made in $50 \mathrm{ml}$ falcon. Pellet was dissolved in $1.5 \mathrm{ml}$ of $50 \mathrm{mM}$ Tris-HCL buffer (pH 8). Equal amount of pellet mixture and $2 X$ loading dye was mixed in an eppendorf and heat shocked for 3-5 min. sample was run on sodium dodecyl sulphate poly acrylamide gel electrophoresis (SDS-PAGE). The supernatant was checked for polymerasel.

\section{Large scale prepartion of Polymerase I}

$500 \mathrm{ml}$ of LB broth, inoculated with BL-21 codon plus cells (Pol-pET22b8.0) and induced wih $5 \mathrm{mM}$ lactose incubated at $37^{\circ} \mathrm{C}$ for $6 \mathrm{hr}$. The culture was $6500 \mathrm{~g}$ for $15 \mathrm{~min}$. Supernatant was discarded and 10 $\mathrm{ml}$ of $50 \mathrm{mM}$ tris- $\mathrm{Cl} \mathrm{pH} 6.8$ was added to the pellet. The procedure was repeated twice to wash the pellet.

Sonication to lyse the cells

In $50 \mathrm{ml}$ falcons the samples were sonicated for $1 \mathrm{hr}$. Samples were sonicated as 30 sec cycle and after each cycle 1 min rest was given, whole sonication procedure was carried by keeping samples on ice. Samples were centrifuged at 10,000 g for 20 minutes and shifted the supernatant to sterile falcons and re- 
suspended pellet in $10 \mathrm{ml} 50 \mathrm{mM}$ Tris-Cl pH 6.8. Soluble fraction (supernatant) and insoluble fraction (pellet) was checked for polymerase I. Supernatant and pellet were analyzed on SDS-PAGE.

Expression of Polymerase I in codon plus BL-21 cells

Pol-pET22b8.0 was transformed to BL-21 codon plus cells. Single transformed colony was inoculated in $10 \mathrm{ml} \mathrm{LB}$ ampicilin flask and incubated at $37^{\circ} \mathrm{C}$ in shaker overnight. $1 \mathrm{ml}$ culture was taken from inoculum and inoculated in $50 \mathrm{ml}$ LB fresh media flask and incubated at $37^{\circ} \mathrm{C}$ in shaker until optical density (OD) 600 reached to $0.4-0.6$. At this stage $0.05,0.1,0.2,2 \mathrm{mM}, 5 \mathrm{mM}, 10 \mathrm{mM}, 15 \mathrm{mM}$ and $20 \mathrm{mM}$ lactose concentration was added to the culture and again incubated culture in shaker for 5-6 hours. From this induced culture pellet was made in $50 \mathrm{ml}$ falcon. Pellet was dissolved in $1.5 \mathrm{ml}$ of $50 \mathrm{mM}$ TrisHCL buffer ( $\mathrm{pH} 8$ ). Equal amount of pellet mixture and $2 \mathrm{X}$ loading dye was mixed in an eppendorf and heat shocked for 3-5 min. sample were loaded on sodium dodecyl sulphate poly acrylamide gel electrophoresis (SDS-PAGE). The supernatant was checked for polymerase I.

\section{Purification of polymerase I}

Supernatant was saturated with $30 \%, 40 \%, 50 \%, 60 \%, 70 \%$ \& $80 \%$ ammonium sulphate. All the samples were analyzed on $12 \%$ SDS PAGE. The protein of interest was precipitated on $40 \%$ saturation with ammonium sulphate. The quantity of the protein in the sample was estimated by the UV absorption method. Pre packed Hitrap ${ }^{\mathrm{TM}}$ SP Sepharose Fast Flow $5 \mathrm{ml}$ cation exchange column was used to carry out the ion exchange chromatography for purification of protein. The column is packed with sepharose which is $6 \%$ highly cross linked agarose and is a strong cation exchanger. Bead size of the resin is 45 $165 \mu \mathrm{m}$, stable at $\mathrm{pH} 4-12$, stored at 4 to $30^{\circ} \mathrm{C}$ in $20 \%$ ethanol. The column was run at rate of $1 \mathrm{ml} / \mathrm{min}$. after collecting the flow through and washings the salt gradient was applied from $0-1 \mathrm{M} \mathrm{NaCl}$ and fractions were collected in sterile eppendorfs by monitoring the peaks on chromatogram to analyze on SDS-PAGE.

\section{Enzyme activity}

PCR amplification of the polymerase / gene was done to check the activity of the enzyme (pol-1) by using Pol-F and Pol-R primers. Reaction mixture was prepared in three PCR tubes. Own heat treated crude enzyme extract was added in one tube, purified protein was added to second tube \& commercial taq polymerase (Thermofisher) was added to the third tube. The conditions used for PCR were initial denaturation at $94^{\circ} \mathrm{C}$ for 3 minutes, denaturation at $94^{\circ} \mathrm{C}$ for $30 \mathrm{sec}$, annealing at $55^{\circ} \mathrm{C}$ for 1 minute, extension at $72^{\circ} \mathrm{C}$ for 1 minute and final extension at $72^{\circ} \mathrm{C}$ for 10 minutes. PCR product was analysed on $1 \%$ agarose gel.

\section{Results And Discussion}

Amplification of Polymerase I gene from Geobacillus kaustophilus 
PCR was optimized by using template sequence of Geobacillus kaustophilus (figure 1) at $94^{\circ} \mathrm{C}$ for 3 min, denaturation at $94^{\circ} \mathrm{C}$ for 30 seconds, annealing at $55^{\circ} \mathrm{C}$ for $1: 30$ min, elongation at $72^{\circ} \mathrm{C}$ for 1 minute and final extension for 10 minutes at $72^{\circ} \mathrm{C}$.

PCR product of $2.6 \mathrm{~Kb}$ (figure 2) was excised from agarose gel and ligated with $p T Z 57 R / T$ and restricted with $\mathrm{NcO} 1$ and $\mathrm{BamH} 1$ and ligated to $\mathrm{pET} 22 \mathrm{~b}$. Cloning in $\mathrm{pET} 22 \mathrm{~b}$ was confirmed by $\mathrm{NcO}$ I and $\mathrm{BamHI}$ (figure 3 and figure 1s-supplementary file).

Expression of polymerase I was checked on BL21 codon plus cells, transformed with pol-pET22b8.0. Culture was induced with $0.05,0.1,0.2,0.5$ and $1 \mathrm{mM}$ IPTG and 2, 5,10, 15 and 20mM lactose.. A band of $99 \mathrm{kDa}$ shows expression of polymerase I (Figure 4 and $5 \mathrm{~b}$ ).

Maximum expression of polymerase I was observed with $20 \mathrm{mM}$ lactose. After sonication the analysis of protein showed, polymerase I was present in supernatant of sonicated samples.

After harvesting cells in 50mM Tris buffer ( $\mathrm{pH} 6.8)$, the cell suspension was lysed by sonication and the suspension was centrifuged to obtain the supernatant as the desired protein was soluble and it was present in the supernatant fraction. The protein was purified by heat treating the cell lysate at $60^{\circ} \mathrm{C}$ for 20 min and centrifuging at 10,000 rpm for $20 \mathrm{~min}$ and separating the supernatant (figure 6). The heat treated lysate was further purified by passing through cation exchange column, desired protein was eluted at $1 \mathrm{M}$ $\mathrm{NaCl}$ concentration. Polymerase I was precipated at $40 \%$ saturation of ammonium sulfate.

On FPLC column polymerase I was eluted with $1 \mathrm{M}$ concentration of $\mathrm{NaCl}, 5.86 \mathrm{mg}$ of protein was loaded on ion exchange column and $1.952 \mathrm{mg}$ (figure 5a).

DNA polymerase I has $5^{\prime}-3^{\prime}$ polymerase activity and $3^{\prime}-5^{\prime}$ exonuclease activity. It fills the gaps which arises during DNA replication, repair and recombination. Sequencing results shows ten silent mutations in DNA polymerase I gene of Geobacillus SBS 4S (figure 2s).

Polymerase I from Geobacilus sp. was found to be 99KDa protein on SDS-PAGE, Taq DNA polymerase was cloned and expressed in E.coli. and molecular weight determination on SDS-PAGE showed a $94 \mathrm{KDa}$ protein The purified enzyme retained the activity comparable to commercial Taq DNA polymerase (7).

The gene coding for DNA polymerase I from Geobacillus Sp. SBS 4 strain was cloned in to the pET $22 \mathrm{~b}+$ expression vector using $\mathrm{NcOl}$ and $\mathrm{BamHI}$ restriction sites. The construct was transformed in the E.coli strain BL 21 codon + and was grown on Luria-Bertani media (LB).

The Isopropyl- $\beta$-D-thiogalactopyranosid (IPTG) was used as an inducer of interested gene expression under the control of T7 promoter by using $0.05 \mathrm{mM}, 0.1 \mathrm{mM}, 0.2 \mathrm{mM}, 0.5 \mathrm{mM}, 1 \mathrm{mM}$ IPTG induction. The optimization of enzyme induction by IPTG with shake flask was found to be $0.5 \mathrm{mM}$ at exponential growth phase. The lactose was used as an inducer of expression of gene of interest under the control of T7 promoter by using $2 \mathrm{mM}, 5 \mathrm{mM}, 10 \mathrm{mM}, 15 \mathrm{mM}$ and $20 \mathrm{mM}$ lactose induction. The optimization of enzyme induction by lactose with shake flask was found to be $20 \mathrm{mM}$ at exponential growth phase. The 
expression of gene of interest was very high with the lactose inducer and lactose is also a cheaper chemical as compared to IPTG which is an expensive chemical, so lactose inducer was used for further large scale culture preparation.

DNA polymerase I is a single polypeptide chain encoded by $\mathrm{pol} A$ gene. It consists of three distinct domains $\mathrm{C}, \mathrm{N}$ and central domains. Domain $\mathrm{C}$ involves into main DNA polymerase activity while central domain and domain $\mathrm{N}$ are involved in $3^{\prime}-5^{\prime}$ exsonuclease activity and $5^{\prime}-3$ exonuclease activity respectively (8). Domain $\mathrm{C}$ is most important domain that is further divided into three subdomains designated as thumb, palm and fingers with highly conserved motifs $A, B$ and $C$ respectively (9). The palm subdomain has catalytic center and contains conserved carboxylate residues while subdomains fingers and thumb are involved into binding of DNA and incoming dNTPs during replication (10). Ten silent mutations were observed in polymerase I gene with one silent mutation in the C-terminal domain.

Cloning of DNA polymerase I from a thermophilic Rhodothermus marinus was done in E.coli. Sequence analysis of protein showed mutation at 756 position where phenylalanine was substituted by tyrosine. The protein polymerization activity was found to be 3100 units/mg of protein with retaining $3^{\prime}-5^{\prime}$ and $5^{\prime}-$ 3 ' exonuclease activities (11).

DNA polymerase from Pyrococcus KOD1 strain encode for 1671 amino acids polymerase I gene was expressed in E.coli (12). DNA polymerase from Geobacillus sp. SBS 4S was sequenced and purified for the first time. After heat treatment, ammonium sulphate precipitation and FPLC the protein was $99 \%$ pure and was successfully used in a PCR reaction.

Conclusions: DNA polymerase I gene from a local isolate Geobacillus SBS 4S was successfully cloned and expressed in E.coli system. PelB leader sequence attached to the $\mathrm{N}$-terminus of the protein makes the protein soluble. The expresson was optimized at $0.5 \mathrm{mM}$ concentration of IPTG and 20mM lactose. Polymerase I was purified by ammonium sulphate precipitation and ionexchange chromatography.

\section{Declarations}

Abbreviations: not applicable

Ethics approval and consent to participate: not applicable

Consent for publication: Not applicable

Availability of data and materials: Not applicable

Competing interests: Not applicable

Funding: Funding is from the research funding for MS student of Biotechnology, LCWU.

Authors' contributions: Farheen Aslam and Saima Iftikhar Bajwa conceived and designed the experiments, analyzed the data and wrote the paper. 


\section{References}

1.Yazd EF, Sadeghizadeh M, Hosseinkhani S, Khalaj-Kondori M, Emamzadeh R. Molecular cloning, expression and sequence analysis of DNA polymerase I from an Iranian thermophilic bacterium, Bacillus sp. G (2006). Journal of the Iranian Chemical Society. 2009;6(4):831-7.

2.Beckman RA, Loeb LA. Multi-stage proofreading in DNA replication. Quarterly reviews of biophysics. 1993;26(3):225-331.

3.Kim DJ, Pyun YR. Cloning, Expression, and Characterization of Thermostable DNA Polymerase from Thermoanaerobacter yonseiensis. Biochemistry and Molecurar Biology Reports. 2002;35(3):320-9.

4.Pramono H, Ambarsari L, Susanti E, Nurbaiti S, Madayanti F. Cloning, Homological Analysis, and Expression of DNA Pol I from Geobacillus thermoleovorans. International Journal of Integrative Biology. 2008;1:206.

5.Zeigler DR. The genus Geobacillus. Introduction and strain catalog. Catalog of strains. 2001;3.

6.Sambrook J, Russell D. Molecular cloning: A laboratory manual, the third edition. Cold spring harbor laboratory press, cold spring harbor, New York; 2001.

7.Roayaei M, Galehdari H. Cloning and expression of Thermus aquaticus DNA polymerase in Escherichia coli. Jundishapur Journal of Microbiology. 2007;1(1):1-5.

8.Rentier-Delrue F, Mande SC, Moyens S, Terpstra P, Mainfroid V, Goraj K, et al. Cloning and overexpression of the triosephosphate isomerase genes from psychrophilic and thermophilic bacteria: structural comparison of the predicted protein sequences. Journal of molecular biology. 1993;229(1):85-93.

9.Eichler J. Biotechnological uses of archaeal extremozymes. Biotechnology advances. 2001;19(4):26178.

10.Caglayan M, Bilgin N. Cloning and sequence analysis of novel DNA polymerases from thermophilic Geobacillus species isolated from hot springs in Turkey: characterization of a DNA polymerase I from Geobacillus kaue strain NB. Applied Biochemistry and Biotechnology. 2011;165(5-6):1188-200.

11.Thorarinn B, Sigrıdur H, Thorbjarnardo T, Jan K, Sigrıdur H, Jakob K, Kristjansson.,, et al. Cloning, sequence analysis and functional characterization of DNA polymerase I from the thermophilic eubacterium Rhodothermus marinus. Biotechnol Appl Biochem. 2001;34:37-45.

12.Takagi $M$, Nishioka $M$, Kakihara $H$, Kitabayashi $M$, Inoue $H$, Kawakami B, et al. Characterization of DNA polymerase from Pyrococcus sp. strain KOD1 and its application to PCR. Appl Environ Microbiol. 1997;63(11):4504-10. 


\section{Tables}

Table 1: Sequence, GC content, melting temperature and restriction sites of primers.

\begin{tabular}{|c|l|c|c|c|c|}
\hline $\begin{array}{c}\text { Primer } \\
\text { name }\end{array}$ & \multicolumn{1}{|c|}{ Sequence 5'-3' } & $\begin{array}{c}\text { GC } \\
\text { content } \\
(\%)\end{array}$ & $\begin{array}{c}\text { Number of } \\
\text { nucleotide }\end{array}$ & $\begin{array}{c}\text { Melting } \\
\text { temperature }\end{array}$ & $\begin{array}{c}\text { Restriction } \\
\text { sites }\end{array}$ \\
\hline Pol-F & CCATGGCCTTGAAAAAAAAGCTTGTTT & 37.04 & 27 & 63.7 & CCATGG \\
\hline Pol-R & AAGCTTTTATTTCGCGTCATACCATGTCGAG & 42 & 31 & 69.7 & AAGCTT \\
\hline Pol-I & ATGACATCGTCTATCAAGGGGAAGACC & 48 & 27 & 59.7 & - \\
\hline
\end{tabular}

*Forward Primer contains NCoI Restriction site (CCATGG)

**Reverse Primer contains HindIII Restriction site (AAGCTT)

Figures 


$$
\text { 5'--CCATGGCCTTGAAAAAAAAGCTTGTTT--3' }
$$

ATTGCGCCTTATCACGAG ATGAGATTGAAAAAAAA GCTTGTTTTAA TCGACGGCAGCAGCGTGGCGTA CCGCGCCTTTTTTGCCTTGCCGCTTTTGCATAACGACAAAGGCATCCATACGAACGCCGTCTACGGGTT TA CGATGATGTTGAATAAAATTTTGGCGGAAGAAGAGCCAACTCATATGCTTGTCGCGTTTGACGCCG GGAAAACGACGTTCCGGCATGAA GCGTTTCAAGAGTATAAAGGTGGGCGCCAGCAGACGCCACCGGA GCTGTCGGAGCAGTTTCCGCTG TTGCGCGAGCTGCTGAGGGCATATCGCATCCCCGCCTATGAACTCG AGAACTACGAAGCGGA CGATATTATCGGAACGCTTGCCGCCCGCGCTGAGCAGGAAGGGTTTGAGGT GAAAGTCATTTCCGGCGACCG CGATCTGACCCAGCTCGCCTCCCCCCATG TGACGGTGGACATTACGA AAAAAAGGGATTACCGATATCGAA CCATACACGCCGGAGACGGTCCGCGAAAAATACGGCTTA.ACTCC GGAACAAATCGTTGATTTGAAAGGATTGATGGGCGACAAATCGGACAACATCCCCGGAGTGCCGGGC ATCGGGGAAAA GACGGCGGTCAAGCTGCTCAGGCAATTCGGCA CGGTCGAAAATGTGCTTGCCTCCAT TGACGAGATCAAAGGCGAAAAG TTGAAA GAAACGCTGCGCCAACA CCGGGA GATGGCGCTGTTAAGC AAAAAGCTCGCCGCCATTCGCCGCGA CGCCCCGGTCGAGCTCTCGCTTGATGA CATCGTCTATCAAGG GGAAGACCGGGAGAAAGTGGTCGCTTTATTTAAAGAGCTTGGGTTTCAATCGTTTTTAGAGAAAATGG AA TCGCCGTCATCAGAAG AGGAAAAAACCGCTTGCCAAGATGGCATTTACGCTTGCTGACCGCGTGACG GAGGAGATGCTTGCCGACAAGGCGGCGCTTGTCGTTGAA GTGGTCGAGGAAAA TTATCATGATGCGCC GA TCGTCGGCATCGCTGTGGTCAACGAACATGGACGGTTTTTCCTGCG CCCGGAGACGGCGCTTGCCG ATCCGCAGTTTG TCGCCTGGCTTGGTGATGAAACGAAGAAAAAAAAGCATGTTTGACTCAAAG CGCGCG GCAGTCGCCTTGAAA TGGAAAGGAATTGAGCTATGCGG CGTTTCCTTTG ATTTATTGCTGGCCGCCTAT TTGCTTGATCCGGCGCAAGGTGTTGATGATG TAGCTGCCGCAGCCAAAAATGAAGCAATACGAAGCGGT GCGCCCGGATGAAGCGGTGTATGGCAAAGGGGCGAAGCGGGCCGTGCCGGATGAGCCAGTGCTAGCC GAGCATCTCGTCCGCAAGGCGGCGGCGATTTGGGAGCTCGAACGGCCGTTTTTGGATGAGCTGCGCCG CAACGAA CAAGATCGGTTGCTCGTCGAGCTTGA GCAGCCGTTGTCTTCGATTTTGGCGGAAATGGAAT TTGCCGGAGTGAAAGTGGATACGAAGCGGCTCGAACAGATGGGCAAAGAGCTCGCCGAGCAGCTCGG CACGGTCGAGCAGCGCATTTATGAGCTCGCCGGCCAAGAATTCAACATCA.ATTCACCGAAACAGCTCG GCGTCATTTTATTTGAAAAACTGCAGCTGCCCGTCTTGAAAAAAAACGAAAACCGGCTACTCCACTTCG GCGGATGTGCTTGAAAAACTTGCGCCTTATCACGAGATCGTGGAAAACATTTTGCATTACCGCCAGCT TGGCA AGTTGCAGTCGACGTA TATTGAAAGATTGCTGAAAGTCGTG CGACCCGATACAAAGAAGGTGC ATACGATTTTCAATCAGGCGTTGACGCAAACCGGACGGCTCAGCTCGACGGAGCCGAACTTGCAAAAC ATTCCGATTCGGCTTGAGGAAGGACGGAAAATCCGCCAAGCGTTCGTGCCGTCGGAGTCTGATTGGCT CATTTTCGCCGCCGACTACTCACAAATTGAGTTG CGCGTCCTCGCCCATATTGCGGAAGATGACAATTT AA TGGAAG CGTTCCGCCGCGATTTGGA TATCCATACGAAAACAGCGATGGACATTTTCCAAGTGAGCG AGGACGAAGTGACGCCCAACATGCGCCGTCAGGCGAAGGCGGTCAACTTTGGGATCGTTTACGGGAT CAGTGATTACGGCTTGGCGCAAAACTTAAATATTTCGCGCAAAGAGGCGGCTGAA TTCATCGAGCGCT ACTTCGAAAGCTTCCCTGGCGTGAAGCGGTATATGGAAAAACATTGTGCAAGAAGCA.AAACAGAAAGG GTATGTGACGACGCTGCTGCATCGGCGCCGCTATTTGCCGGATATCACGAGCCGCAACTTCAACGTCC GCAGCTTTGCGAACGGATGGCGATGAACACGCCGATTCAAGGGAGCGCCGCTGACATTATTAAAAAG GCGATGATCGATCTGAACGCCAGACTGAAGGAAGA GCGGCTGCAAGCGCGCCTTTTGCTGCAGG TGC ATGACGAGCTCATTTTGGAGGCGCCGAAAGAA GAGATGGAGCGGCTGTGCCGGCTCGTTCCGGAAGT GA TGGAGCAAGCGGTCACA CTTCGCGTGCCGCTCAAAGTCGATTACCATTACGGCTCGACATGGG TCA AA GTCGATTACCATTACGGCTCGACATGGTATGACGCGAAATAA

\section{3'---GAGCTGTACCA TAC TGCGCTTTATTTTCGAA--5'}

Reverse Primer potR

\section{Figure 1}

Sequence of Polymerase I gene ( NCBI ) and sequence of primers. Restriction sites shown in green. Start and stop codons are shown in pink.

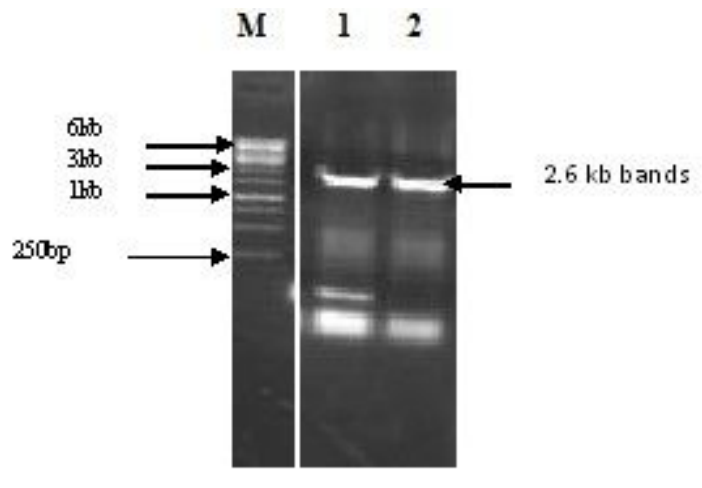


Figure 2

Agarose gel electrophoresis showing PCR amplification of Polymerase I gene. Lane M: Gene Ruler DNA ladder mix. Lane 1 and 2: PCR product of $2.6 \mathrm{~kb}$.

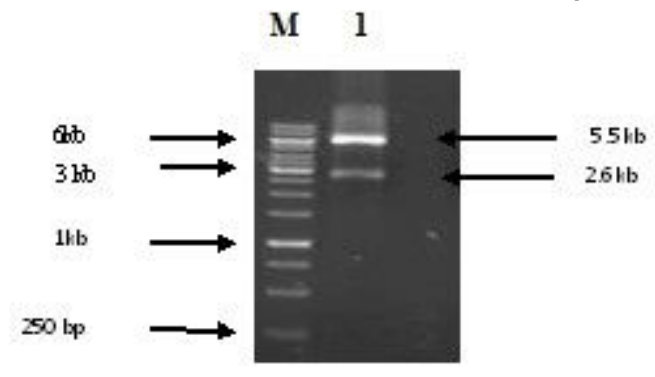

\section{Figure 3}

Agarose gel of restriction analysis of pol-pET 22b 8.0 with Ncol and BamHI. M: DNA marker, lane 1: polpET 22b 8.0 restricted with $\mathrm{Ncol}$ and BamHI.

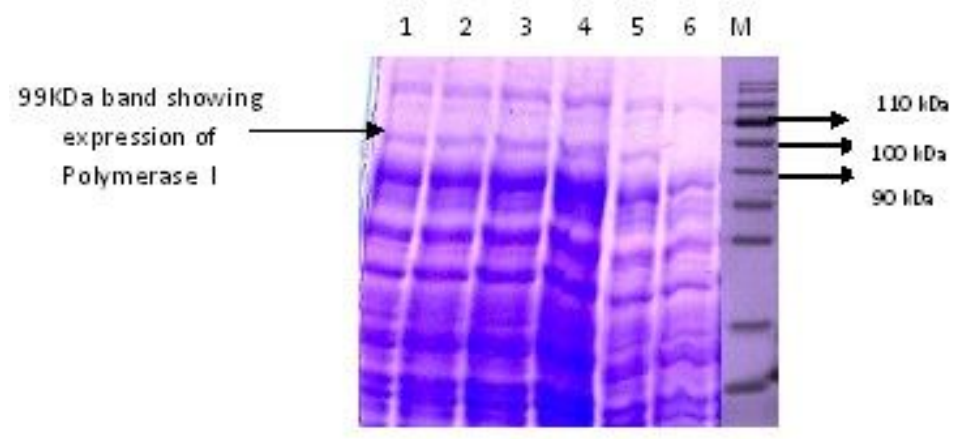

Figure 4

SDS PAGE of induced and uninduced sample of BL21 cells containing Pol-pET 22b 8. Lane 1, 2, 3, 4, and 5 showed polymerase I expression with $0.05,0.1,0.2,0.5$ and $1 \mathrm{mM}$ con-centration of IPTG. Lane 6 : uninduced sample. 


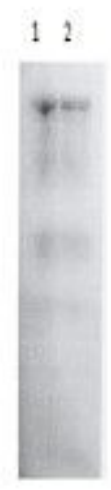

(a)

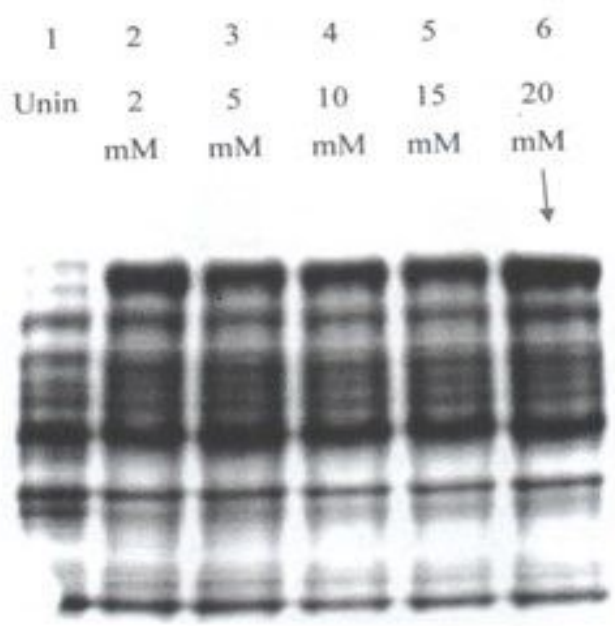

(b)

\section{Figure 5}

(a) Purified Polymerase I after ion exchange chromatography on 12\% SDS-PAGE. (b) Ex-pression of Polymerase I with $2 \mathrm{mM}, 5 \mathrm{mM}, 10 \mathrm{mM}, 15 \mathrm{mM}$ and $20 \mathrm{mM}$ concentration of lac-tose.

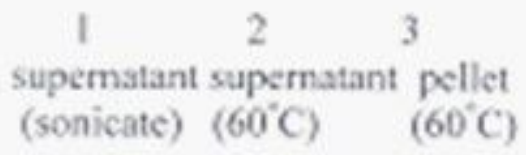

$99 \mathrm{KDa}$
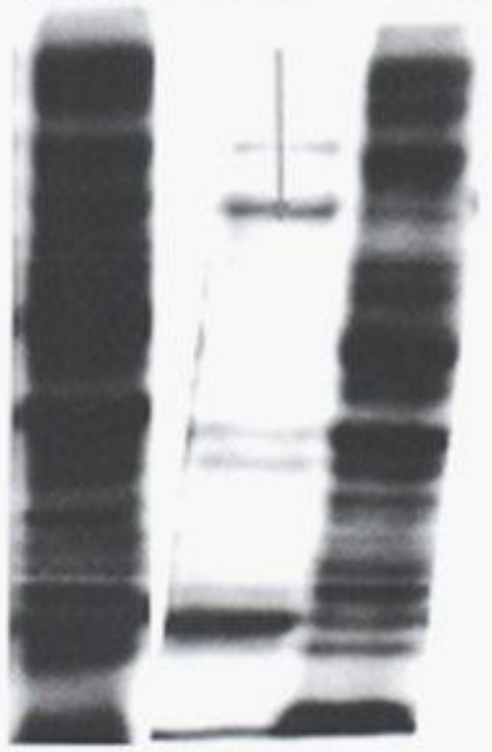

\section{Figure 6}

The supernatant and pellet checked after heat treatment at $60 \mathrm{oC}$. Lane 1: without heat treatment. Lane 2 $\& 3$ supernatant and pellet after heat treatment at $60 \mathrm{oC}$.

\section{Supplementary Files}


This is a list of supplementary files associated with this preprint. Click to download.

- Supplementrydata.docx 